\title{
Effect of gamma-irradiated textile effluent on plant growth
}

\author{
Fahmida Parvin • Zannatul Ferdaus • \\ Shafi M. Tareq • Tasrina R. Choudhury • \\ Jahid M. M. Islam • Mubarak A. Khan
}

Received: 4 May 2014/Accepted: 17 December 2014/Published online: 10 January 2015

(C) The Author(s) 2015. This article is published with open access at Springerlink.com

\begin{abstract}
Introduction Textile industry produces large quantities of highly colored effluents, which are generally toxic and resistant to biodegradation. The present study was carried out to find out the efficiency of using gamma radiation to degrade or decontaminate combined textile effluent and its potential application as irrigation water on spleen amaranth.

Results The change of absorption spectra, physicochemical parameters of gamma-irradiated textile effluent revealed that all these properties have improved after irradiation at (10-15) kGy. Analysis of ammonium and total nitrogen concentration of the effluent also showed that both of them are increased after irradiation and can be used for irrigation purposes. Application of irradiated textile effluents on spleen amaranth have increased dry mass $(10.77 \mathrm{~g})$, plant height $(10.53 /$ week $)$, root length (19.00 $\mathrm{cm}$ ), number of leaves (6/week) compared to the plants which were nourished with raw textile effluent and only water. Elemental analysis showed trace amount of heavy metal uptake by the plant. Moreover, the plants contain mineral nutrients essential for plant growth.
\end{abstract}

F. Parvin $(\bowtie) \cdot$ Z. Ferdaus

Department of Environmental Sciences, Jahangirnagar

University, Savar, Dhaka, Bangladesh

e-mail: fahmidaprvn497@gmail.com

S. M. Tareq

School of Biosciences, The University of Nottingham, Jalan

Broga, 43500 Semenyih, Selangor Darul Ehsan, Malaysia

T. R. Choudhury · J. M. M. Islam · M. A. Khan ( $₫)$

Institute of Radiation and Polymer Technology, Bangladesh

Atomic Energy Commission, Dhaka, Bangladesh

e-mail: makhan.inst@gmail.com
Conclusions The treatment of textile effluents by gamma irradiation $(10-15 \mathrm{kGy})$ is a promising tool as it produces zero waste and has the possibility of alternative use for irrigation water with fertilizing properties.

Keywords Textile effluent - Gamma radiation - Plant . Irrigation water $\cdot$ Fertilizing effect

\section{Introduction}

Textile effluents contain substantial pollution loads in terms of high alkalinity, high biological oxygen demand (BOD), high chemical oxygen demand (COD) and high suspended solids (SS). It also contains dye particle at a high concentration (Selambakkannu et al. 2011) and most of these are non-biodegradable. Existing conventional treatment using physical and chemical treatment is not capable of decomposing the recalcitrant and toxic organic pollutants rather it transfers the pollutants from a liquid medium to a solid medium via coagulation/chemical process (Rabby 2011). A number of research have been going on adsorption processes (Panda et al. 2009; Islam et al. 2013), but those are costly, time consuming and cannot produce zero waste. Biological methods are simple in applications, generally cheap and often used to remove organics and color of textile effluent. However, dye containing effluent cannot be readily degraded by conventional biological processes, e.g., activated sludge process, because the structure of most commercial dye compounds are generally complex and many dyes are non-biodegradable due to the chemical nature and molecular size (Kim et al. 2002). And this process is also time consuming. So it is required to look for a most effective, less time consuming, zero waste producing wastewater treatment technology. 
Ionizing radiation (known as electron beam and gamma radiation) is promising for the treatment of textile dye solution because the effect of radiation can be intensified in aqueous solution, in which the dye molecules may be degraded effectively by the primary products formed through radiolysis of water (Dahlan 2001; Wang et al. 2006; Takács et al. 2007; Selambakkannu et al. 2011). However, to the best of our knowledge, radiation-induced decoloration and degradation of the true textile mill effluent has not performed yet.

Industrial textile effluent contains azo dyes. So after irradiation it may convert into amide, which can be converted into ammonium by hydrolysis (Bagyo et al. 1997). So, this decontaminated wastewater containing nitrogen compound could be used for irrigation. Spleen amaranth is rejuvenator (rasayana) and useful in the treatment of fevers, cough, rheumatism, paralysis, tremors, kapha and vata disorders (Grubben and Denton 2004). Because of this importance, spleen amaranth was chosen to evaluate the fertilizing effect of irradiated textile effluent. Keeping in view the above-cited facts, the present study was carried out to find out the efficiency of using gamma radiation to degrade or decontaminate combined textile effluent and its potential application as irrigation water on spleen amaranth.

\section{Experimental}

\section{Sampling and irradiation}

Effluents used in this research were obtained from a textile industry which is located at Ganda, Savar, Bangladesh. The sample was a mixture of wastewater produced from several processes such as washing, dying, waxing and rinsing. The samples were irradiated by gamma rays from the cobalt- 60 gamma radiation source. The dose was determined by Amber Perpex dosimeter; type 3042F. In this study 10-25 kGy dose have been chosen for irradiation as lower doses were not sufficient for complete mineralization of textile effluent (Takács et al. 2007).

\section{Physicochemical analysis}

Samples were analyzed before and after irradiation. $\mathrm{pH}$, EC, TDS and DO of both irradiated and raw samples were measured using portable multiparameter (Model no-sension $^{\text {TM }}$ 156, Supplier-Hach Company USA, 2000) within half an hour of the collection of sample. The turbidity of the samples is also measured by turbidity meter HANNA H193703 microprocessor turbidity meter, range (0.00-1000) FTU (Formazin Turbidity Unit). The BOD of the samples was determined by 5 -day BOD test at $20{ }^{\circ} \mathrm{C}$ temperature of over an elapsed period of 5 days in the dark. The COD of the samples was determined by closed reflux, titrimetric method. The concentration of nitrogen and ammonium was determined by the Kjeldahl and Kjeldahl distillation methods, respectively (Mulvaney 1996). UVVisible spectra of irradiated and raw textile effluent were obtained by T-60 UV-visible spectrophotometer using quartz cell (size $10 \times 10 \mathrm{~mm}$ ) in UV-win 5 software.

\section{Analysis of fertilizing effects}

The irradiated and raw textile effluents were irrigated into spleen amaranth to observe the fertility effect of gamma ray-irradiated textile effluents using pot experiments. Six pots of spleen amaranth (three replications) have prepared by adding garden soil with the appropriate moisture content where they were successively nourished by water, raw and the irradiated (10-25) kGy textile effluent. In every week, the plants were monitored prior to measuring the plant height, maximum leaf area, number of leaves to compare the effect of irradiated textile effluent with the raw and control one.

The plant heights were measured from the border of the pot to the top of the main plant stem. It was not measured from the top of the soil; as the soil was condense with watering over time. To measure the number of leaves, every visible leaf of each plant was counted including the tips of new leaves just beginning to emerge. For measuring the leaf area, the leaves were traced on graph paper and the squares covered were counted to get an estimate of the surface area for each leaf (Parvin et al. 2013). At 55 DAS (days after sown) the plants were harvested and lengths of roots were measured. The plants were dried in oven at $105{ }^{\circ} \mathrm{C}$ for $12 \mathrm{~h}$ (Mollah et al. 2009) and after half an hour interval the weight was taken to measure the dry mass.

\section{Elemental analysis of samples}

After irradiation the textile effluent was analyzed by atomic absorption spectrophotometer (AAS) prior to determine the changes in metal concentration. $\mathrm{Cu}, \mathrm{Cd}, \mathrm{Zn}, \mathrm{Co}, \mathrm{Cr}, \mathrm{Mn}$, $\mathrm{Ni}, \mathrm{Pb}, \mathrm{Na}, \mathrm{K}, \mathrm{Cu}, \mathrm{Fe}, \mathrm{Zn}, \mathrm{Mg}$ and $\mathrm{Mn}$ were analyzed using flame AAS (Varian AA240FS), As by hydride generation AAS (Varian AA240) and $\mathrm{Hg}$ by cold vapor AAS (novAA350, Analytik jena). The calibration curves were prepared for each element individually applying linear correlation by least square method.

The samples of spleen amaranth and the soil that was used for the planting of spleen amaranth were also analyzed to determine the concentration of trace metals. Dried samples of soil and vegetable were ground into a fine powder (80 mesh size) using a mortar and duplicate samples $(0.3 \mathrm{~g})$ of each vegetable and soil samples were 
weighted in digestion flask and treated with $3 \mathrm{ml}$ of concentrated $\mathrm{HNO}_{3}$. Digestions of solid sample (soil and plant) were carried out in microwave-accelerated reaction system (MARS); model no-MARS 5.

\section{Results and discussions}

Changes of physicochemical parameter of the textile effluent after irradiation

The $\mathrm{pH}$ of the textile wastewater which was collected from the industry was 10.33 . But after irradiation, at $10 \mathrm{kGy}$ the $\mathrm{pH}$ of the effluent is reduced to 8.14 which comply with the limit of Bangladesh industrial effluent standards for discharge in irrigated land (Table 1). It may be deduced that the oxidation of aromatic compounds induced by ionizing radiation gives some lower molecular weight aliphatic compounds such as aldehyde and organic acids and that further oxidation of the organic acid formed leads to the formation of carbon dioxide (Spinks and Woods 1964; Suzuki et al. 1975) and lowering of the $\mathrm{pH}$ of the water. But with the augment of absorbed doses the $\mathrm{pH}$ remains almost similar. $10 \mathrm{kGy}$ may be enough to oxidize all the aromatic compounds that remain in wastewater and no more aromatic compound remain to oxidize in elevated absorbed doses.

High $\mathrm{BOD}_{5}(135 \mathrm{ppm})$ and COD (670 ppm) value of the textile wastewater has been decreased dramatically by irradiation and the rate of reduction has increased with increasing absorbed dose. The reduction of $\mathrm{BOD}_{5}$ and COD implies that oxidizable materials found in the sample have been reduced due to complete decomposition of organic pollutants by ionizing radiation (Tchobanoglous and Schroeder 1985; Miyata 1993).

When the textile effluent was exposed to gamma irradiation, the water molecule undergoes radiolysis process to produce ionized and excited water molecules and free electrons (reactive species). Reactions between pollutants and primary products of water radiolysis $\left(\cdot \mathrm{OH}, \mathrm{e}_{\mathrm{aq}}^{-}, \mathrm{H}^{+}\right)$ and secondary short-lived species formed from the pollutants causes the removal of pollutants from the wastewater (Anbar and Neta 1967; Buxton et al. 1988). And these reduced values of $\mathrm{BOD}_{5}$ and COD comply with the limit of Bangladesh industrial effluent standards for discharge in irrigated land (BOD 100 and COD 400 ppm) (GoB, ECR 1997). After gamma irradiation, the DO value of the effluent becomes improved and approaches to the standard value (4.5-8 ppm) for irrigation water (GoB, ECR 1997). This occurs because of decreasing the BOD level, increasing of transparency of the textile effluent and owing to the presence of hydrolysis product of water $\left(\mathrm{O}_{2}, \mathrm{H}_{2} \mathrm{O}_{2}\right.$, etc.,) by the effect of gamma radiation (Miyata 1993).

At $10 \mathrm{kGy}$ irradiation, the turbidity of the effluent is reduced from 161.65-120.95 FTU. The turbidity values decreased with increasing absorbed dose that indicates the reduction of suspended particulate matter and the breaking down of organic particles by the action of gamma radiation. This process also revealed by the reduction of COD (Soutsas et al. 2010; Selambakkannu et al. 2011). Total suspended solids of the textile effluent were also reduced from $440-210 \mathrm{ppm}$ at $10 \mathrm{kGy}$ of gamma irradiation, as they were converted to precipitates resulting from the degradation of organic substances and suspended matter in wastewater (Compton 1971).

TDS value $(3,410 \mathrm{mg} / \mathrm{L})$ of the raw effluent (Table 1) exceeded the standard value of water quality for irrigation (GoB, ECR 1997). But after gamma ray irradiation it becomes lower to 1,410 at the absorbed dose of $15 \mathrm{kGy}$ which indicates the degradation of pollutant in the textile wastewater. There are two probable cause of TDS reduction; one is degradation of dye molecules induced by the reaction with oxidative species from water hydrolysis (Somasiri et al. 2006) and the other reason is the breakdown of larger organic chain into smaller chain adjacent to the main azo or anthraquinone groups $(\mathrm{N}=\mathrm{N}$ bonds) due to radiation (Nickelsen et al. 1992), the TDS value shows an increasing trend at 20 and $25 \mathrm{kGy}$ absorbed doses, but it still remains lower than the standard value of water quality for irrigation. EC is correlated closely with TDS (Rouse 1979) and similar trend of reduction also found in case of EC.
Table 1 Physicochemical parameters of the irradiated and raw sample of textile effluent

\begin{tabular}{lllllll}
\hline Parameter & Unit & Raw effluent & $10 \mathrm{kGy}$ & $15 \mathrm{kGy}$ & $20 \mathrm{kGy}$ & $25 \mathrm{kGy}$ \\
\hline TSS & $\mathrm{mg} / \mathrm{L}$ & 440 & 210 & 240 & 230 & 235 \\
TDS & $\mathrm{mg} / \mathrm{L}$ & 3,410 & 1,620 & 1,410 & 1,850 & 1,730 \\
Turbidity & $\mathrm{FTU}$ & 161.65 & 120.95 & 101.22 & 95.65 & 93.12 \\
DO & $\mathrm{mg} / \mathrm{L}$ & 0.5 & 5.50 & 6.0 & 6.5 & 6.5 \\
$\mathrm{pH}$ & - & 10.33 & 8.14 & 8.13 & 8.17 & 8.16 \\
$\mathrm{EC}$ & $\mu \mathrm{S} / \mathrm{cm}$ & 4,140 & 2,210 & 1,900 & 2,700 & 2,890 \\
BOD & $\mathrm{mg} / \mathrm{L}$ & 135 & 55 & 40 & 45 & 35 \\
COD & $\mathrm{mg} / \mathrm{L}$ & 670 & 255 & 262 & 210 & 222 \\
\hline
\end{tabular}




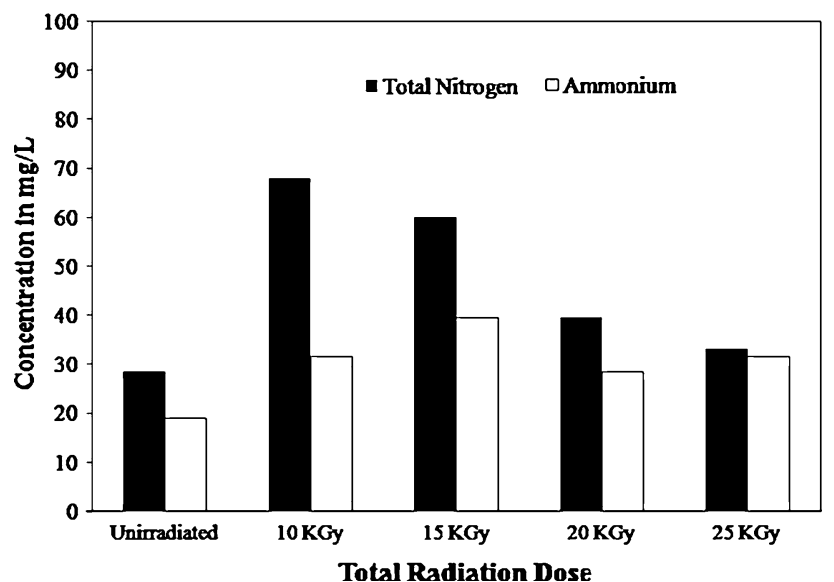

Fig. 1 Comparison of total $\mathrm{N}$ and ammonium content in both irradiated and raw (unirradiated) textile effluent

Changes of total nitrogen and ammonium concentration in textile effluent after gamma irradiation

After gamma irradiation both the nitrogen (N) and ammonia content of the textile effluent has increased. Figure 1 shows that raw textile effluent contains $28.5 \mathrm{mg} / \mathrm{L}$ total $\mathrm{N}$ but after irradiation at $10 \mathrm{kGy}$ the total $\mathrm{N}$ content increased to more than double and amounts to $68 \mathrm{mg} / \mathrm{L}$. Owing to applying radiation, the refractory fractions of the azo dyes have broken down easily and nitrogen molecules come out into the solution rapidly after digestion. Nickelsen et al. (1992) and Somasiri et al. (2006) also revealed that radiation causes the degradation of azo dyes and releases the nitrogen $\left(\mathrm{N}_{2}\right)$ into effluent. Besides this, textile effluent contains azo dye, so after gamma irradiation it was converted into amide, which then converted into ammonium by hydrolysis (Bagyo et al. 1997) and maximum concentration of ammonium ( $39.50 \mathrm{mg} / \mathrm{L})$ was found when the effluent is irradiated at $15 \mathrm{kGy}$. One reason is the degradation of dye molecules induced by the reaction with oxidative species from water hydrolysis (Somasiri et al. 2006) and the other reason is the breakdown of larger organic chain into smaller chain adjacent to the main azo or anthraquinone groups ( $\mathrm{N}=\mathrm{N}$ bonds) due to radiation (Nickelsen et al. 1992).

Analysis of absorption spectra for irradiated and raw textile effluent

The raw textile effluent has very strong absorption bands in visible region at (400-430) and (550-600) nm (Fig. 2). After gamma irradiation the intensity of the main absorption decreased gradually as the dose increased. The changes in absorbance are found in these two regions are due to the presence of green (visible range band $550-650 \mathrm{~nm}$ ) and

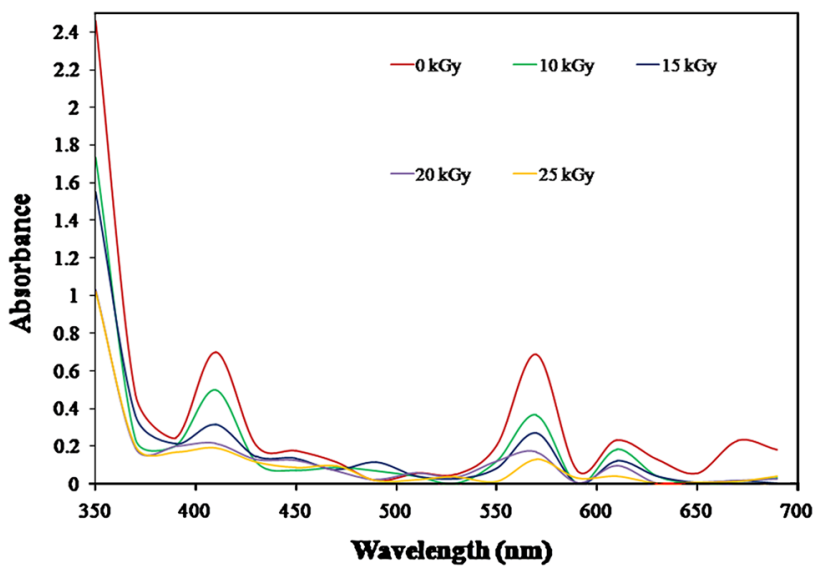

Fig. 2 Changes of absorption spectra for irradiated and raw (0 kGy) textile effluent

blue (visible range band $300-400 \mathrm{~nm}$ ) dyes present in the combined raw effluent collected from the textile industry. These intensity decreases reflects the destruction of conjugated system of the dye molecules by the attack of hydroxyl radicals $(\cdot \mathrm{OH})$ formed by the water hydrolysis with the action of gamma ray radiation. Solphan in (2001) and Sumartono in (2006) has also found that commercial azo dyes and commercial anthraquinone dyes show the sharp changes of absorption peak after irradiation in oxygen-saturated condition.

Elemental analysis of the irradiated and raw textile effluent

The analytical data of various elements concentration in textile effluents and their standard are represented in Table 2. Among the heavy metals lead, chromium, mercury, cobalt, nickel and cadmium have prime importance because they are subject to bioaccumulation and may pose a risk to human health when transferred to the food chain (Itanna 2002). But, analytical results revealed that the concentration of lead, chromium, mercury, arsenic, cobalt, nickel and cadmium in effluents of textile industry for both raw and gamma-irradiated remains within the acceptable limit for the drinking water set by the World Health Organization (WHO 2000) and irrigation water set by DoE (GoB, ECR 1997).

On the contrary, Table 2 also revealed that the nutrient contents like $\mathrm{Na}, \mathrm{K}, \mathrm{Cu}, \mathrm{Fe}, \mathrm{Zn}, \mathrm{Mg}$ and $\mathrm{Mn}$ are considerably higher in irradiated effluents. These are essential micro and macroelements for supporting the plant growth when it will apply in the purpose of irrigation. So these gamma ray-irradiated textile effluent containing $\mathrm{Na}, \mathrm{K}, \mathrm{Cu}$, $\mathrm{Fe}, \mathrm{Zn}, \mathrm{Mg}$ and $\mathrm{Mn}$ has the potentiality as the plant fertilizer sources. 
Table 2 Elements concentration (in $\mathrm{mg} / \mathrm{L}$ ) for raw and gamma-irradiated textile effluent

\begin{tabular}{|c|c|c|c|c|c|c|c|}
\hline Metal name & Raw effluent & $10 \mathrm{kGy}$ & 15 kGy & 20 kGy & 25 kGy & $\begin{array}{l}\text { WHO standard for } \\
\text { drinking water }\end{array}$ & $\begin{array}{l}\text { DoE standard for } \\
\text { irrigation water }\end{array}$ \\
\hline Chromium (Cr) & 0.003 & 0.008 & 0.008 & 0.003 & 0.003 & 0.05 & 1 \\
\hline Lead $(\mathrm{Pb})$ & $<0.02$ & 0.038 & 0.038 & 0.027 & 0.027 & 0.01 & 0.1 \\
\hline Cadmium $(\mathrm{Cd})$ & $<0.004$ & $<0.004$ & $<0.004$ & $<0.004$ & $<0.004$ & 0.003 & 0.05 \\
\hline Cobalt $(\mathrm{Co})$ & $<0.004$ & 0.013 & 0.013 & 0.013 & 0.013 & - & \\
\hline Nickel (Ni) & $<0.004$ & 0.015 & 0.016 & 0.015 & 0.013 & 0.02 & 1 \\
\hline Copper $(\mathrm{Cu})$ & $<0.002$ & 0.092 & 0.056 & 0.072 & 0.057 & 2 & 3 \\
\hline Zinc $(\mathrm{Zn})$ & 0.038 & 0.013 & 0.024 & 0.010 & 0.013 & 3 & 10 \\
\hline Arsenic (As) & $<0.0003$ & $<0.0003$ & $<0.0003$ & $<0.0003$ & $<0.0003$ & 0.01 & 0.2 \\
\hline Mercury (Hg) & 0.001 & 0.001 & $<0.0003$ & $<0.0003$ & $<0.0003$ & 0.001 & 0.01 \\
\hline Iron $(\mathrm{Fe})$ & $<0.004$ & 0.212 & 0.326 & 0.218 & 0.313 & 0.3 & 2 \\
\hline Manganese (Mn) & 0.140 & 0.326 & 0.224 & 0.238 & 0.295 & 0.1 & 5 \\
\hline Magnesium (Mg) & 0.004 & 0.004 & 0.004 & 0.004 & 0.004 & - & \\
\hline Sodium (Na) & 0.123 & 0.723 & 0.775 & 0.718 & 0.686 & 200 & \\
\hline Calcium (Ca) & 0.024 & 0.033 & 0.035 & 0.033 & 0.034 & - & \\
\hline Potassium (K) & 0.001 & 0.02 & 0.022 & 0.019 & 0.019 & - & \\
\hline
\end{tabular}

Table 3 Morphological characters of spleen amaranth

\begin{tabular}{|c|c|c|c|c|c|c|c|c|c|c|c|c|c|c|c|c|c|c|}
\hline \multirow{2}{*}{$\begin{array}{l}\text { Sample } \\
\text { ID }\end{array}$} & \multicolumn{6}{|c|}{ Plant height average $(\mathrm{cm})$} & \multicolumn{6}{|c|}{ No. of leaf average } & \multicolumn{6}{|c|}{ Maximum leaf area $\left(\mathrm{cm}^{2}\right)$} \\
\hline & $\begin{array}{l}20 \\
\text { DAS }\end{array}$ & $\begin{array}{l}27 \\
\text { DAS }\end{array}$ & $\begin{array}{l}34 \\
\text { DAS }\end{array}$ & $\begin{array}{l}41 \\
\text { DAS }\end{array}$ & $\begin{array}{l}48 \\
\text { DAS }\end{array}$ & $\begin{array}{l}55 \\
\text { DAS }\end{array}$ & $\begin{array}{l}20 \\
\text { DAS }\end{array}$ & $\begin{array}{l}27 \\
\text { DAS }\end{array}$ & $\begin{array}{l}34 \\
\text { DAS }\end{array}$ & $\begin{array}{l}41 \\
\text { DAS }\end{array}$ & $\begin{array}{l}48 \\
\text { DAS }\end{array}$ & $\begin{array}{l}55 \\
\text { DAS }\end{array}$ & $\begin{array}{l}20 \\
\text { DAS }\end{array}$ & $\begin{array}{l}27 \\
\text { DAS }\end{array}$ & $\begin{array}{l}34 \\
\text { DAS }\end{array}$ & $\begin{array}{l}41 \\
\text { DAS }\end{array}$ & $\begin{array}{l}48 \\
\text { DAS }\end{array}$ & $\begin{array}{l}55 \\
\text { DAS }\end{array}$ \\
\hline Controlled & 12 & 21.3 & 22 & 27.2 & 35.5 & 43.7 & 7 & 11 & 16 & 22 & 25 & 29 & 14 & 22 & 36 & 48 & 62 & 80 \\
\hline 0 KGy & 12.5 & 16.9 & 19.5 & 21.6 & 27.2 & 32.9 & 8 & 10 & 13 & 16 & 20 & 24 & 15 & 18 & 26 & 38 & 51 & 65 \\
\hline $10 \mathrm{KGy}$ & 11.6 & 25.2 & 34.3 & 46 & 59.4 & 74.8 & 7 & 13 & 20 & 29 & 34 & 42 & 14 & 25 & 47 & 68 & 89 & 110 \\
\hline 15 KGy & 12 & 23 & 32.3 & 44.2 & 53 & 68.3 & 7 & 12 & 18 & 23 & 28 & 35 & 15 & 24 & 42 & 56 & 79 & 98 \\
\hline $20 \mathrm{KGy}$ & 11.3 & 22.6 & 29 & 40.2 & 49 & 66.6 & 7 & 12 & 19 & 22 & 26 & 33 & 13 & 24 & 40 & 52 & 73 & 93 \\
\hline $25 \mathrm{KGy}$ & 11.8 & 21.1 & 25.5 & 31.5 & 39 & 52.4 & 8 & 11 & 17 & 20 & 24 & 31 & 14 & 22 & 41 & 48 & 67 & 88 \\
\hline
\end{tabular}

Fertilizing effect of textile effluent

Application of irradiated textile effluent showed a marked effect on the plant morphology. Plants nourished with textile effluent irradiated at 10 and $15 \mathrm{kGy}$ showed best performance (Table 3) among the plants nourished by effluent irradiated at four different radiation doses, raw textile effluent and control sample, in case of these threegrowth parameters (highest plant height, maximum leaf area and number of leaf average).

Increase of root length indicates the growth of plant. Gamma-irradiated textile effluent has increased the root length of spleen amaranth compared to the controlled sample and sample nourished by raw textile effluent (Fig. 3). Highest root length at 55 DAS was found $19.00 \mathrm{~cm}$ with the treatment of textile effluent irradiated at $10 \mathrm{kGy}$, whereas $14.00 \mathrm{~cm}$ found for controlled sample and $10.33 \mathrm{~cm}$ for raw textile effluent. This indicates that gamma ray-irradiated textile effluent has marked effect on root length. Similar results are also found in case of dry weight. The results suggest that the application of irradiated textile effluent containing the higher concentration of ammonium and nitrogen causes an increase in the biochemical and physiological functions of plants that lead to an increase in dry matter. So for the best production of vegetables total dose of (10-15) kGy at dose rate of $13.0 \mathrm{kGy} /$ $\mathrm{h}$ of gamma radiation is required and the gamma ray-irradiated textile effluent should be applied at three times per week to get the optimal growth results.

Bioaccumulation of elements in spleen amaranth

Heavy metal content as well as the micro and macronutrient content were analyzed for plant irrigated by gamma ray-irradiated textile effluent. The results of metal analysis (Table 4) demonstrate that the concentrations of heavy metal in the plant sample are present in an acceptable limit, 

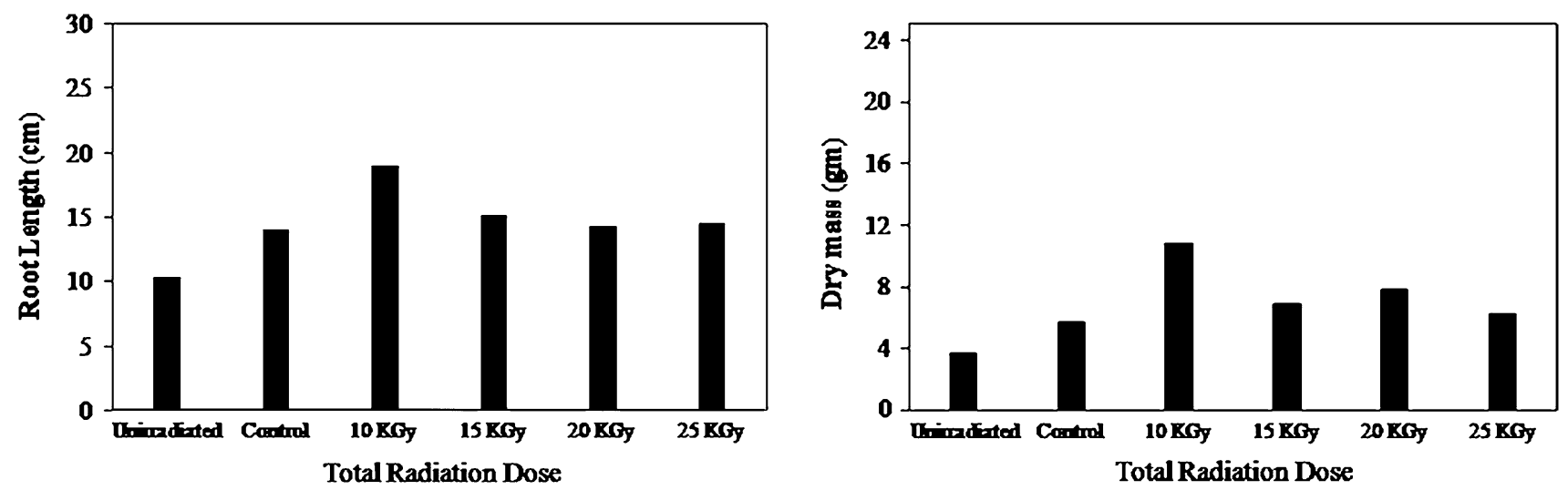

Fig. 3 Comparison of root length and dry mass of spleen amaranth after irrigation with raw (unirradiated) and gamma-irradiated textile effluent at different absorbed doses

Table 4 Elements

concentration $(\mathrm{mg} / \mathrm{kg})$ in spleen amaranth nourished by gammairradiated and raw textile effluent

\begin{tabular}{lllllll}
\hline Metal name & Raw effluent & Control & $10 \mathrm{kGy}$ & $15 \mathrm{kGy}$ & $20 \mathrm{kGy}$ & $25 \mathrm{kGy}$ \\
\hline Chromium $(\mathrm{Cr})$ & 0.76 & 0.55 & 0.60 & 0.40 & 0.48 & 0.63 \\
Lead $(\mathrm{Pb})$ & 3.96 & 1.86 & 2.9 & 1.6 & 1.6 & 2.1 \\
Cadmium $(\mathrm{Cd})$ & 0.12 & 0.12 & 0.44 & 0.5 & 0.6 & 0.3 \\
Cobalt $(\mathrm{Co})$ & 1.86 & 1.56 & 1.63 & 1.53 & 1.6 & 2.03 \\
Nickel $(\mathrm{Ni})$ & 1.01 & $<0.004$ & $<0.004$ & $<0.004$ & $<0.004$ & $<0.004$ \\
Copper $(\mathrm{Cu})$ & 20.59 & 15.64 & 30.76 & 25.72 & 32.66 & 23.80 \\
Zinc $(\mathrm{Zn})$ & 56.62 & 55.2 & 66.35 & 62.56 & 59.93 & 69.94 \\
Arsenic $(\mathrm{As})$ & $<0.1$ & 0.24 & 0.15 & 0.19 & 0.15 & 0.22 \\
Mercury (Hg) & $<0.3$ & $<0.3$ & $<0.3$ & $<0.3$ & $<0.3$ & $<0.3$ \\
Iron (Fe) & 365 & 456.9 & 422.9 & 522.6 & 380.7 & 407 \\
Manganese $(\mathrm{Mn})$ & 0.33 & 0.48 & 0.56 & 0.43 & 0.47 & 0.36 \\
Magnesium (Mg) & 183 & 184 & 244 & 217 & 204 & 194 \\
Sodium (Na) & 4.24 & 14.02 & 62.9 & 6.98 & 8.7 & 11.2 \\
Calcium $(\mathrm{Ca})$ & 101 & 98 & 287 & 119 & 141 & 163 \\
Potassium (K) & 130 & 111 & 182 & 183 & 182 & 156 \\
\hline
\end{tabular}

excepting $\mathrm{Pb}$ and Cd (Itanna 2002; Naser et al. 2011). But their concentrations remain in slightly higher concentration than the acceptable limit.

Elemental analysis of the soil in which the plants were grown were also performed (Table 5). And by analyzing the metal concentration in irradiated textile effluent (Table 2) and soil (Table 5), it has been found that the source of heavy metal in the plant largely come from the soil, not from the effluent.

The concentration of $\mathrm{Cu}, \mathrm{Na}, \mathrm{Ca}, \mathrm{K}$ and $\mathrm{Mg}$ is comparatively higher in the plants nourished by gamma ray-irradiated textile effluent than the plants nourished with raw textile effluent and only water. This is due to the bioavailability of the nutrient from the textile effluent after gamma ray irradiation. In the raw effluent the nutrient element remains as a ligand that binds to the central metal atom in a complex form. But after irradiation the complex form has broken down and the nutrient element becomes available as a free element. And plants are then able to uptake the nutrient from water. Depending upon the exposure route, all these elements $(\mathrm{Cu}$, $\mathrm{Na}, \mathrm{Ca}, \mathrm{K}$ and $\mathrm{Mg}$ ) are least toxic trace elements if ingested (USEPA 1995). Finally it can be easily concluded that the hazardous and toxic elements in the plant are present in negligible amounts but the nutrients essential for plant growth and human health are found in higher rate. So the gamma rayirradiated textile effluents have proved as the fertilizer-containing irrigation water.

\section{Conclusions}

Decoloration and degradation of textile dyes and organic waste in aqueous solutions by gamma irradiation has been accomplished successfully. All the physicochemical 
Table 5 Metal concentration $(\mathrm{mg} / \mathrm{kg})$ in soil used for plantation

\begin{tabular}{ll}
\hline Metal & Concentration \\
\hline Chromium (Cr) & $59.94 \pm 1.1$ \\
Lead $(\mathrm{Pb})$ & $33.96 \pm 2.42$ \\
Cadmium (Cd) & $0.76 \pm 0.01$ \\
Cobalt $(\mathrm{Co})$ & $10.9 \pm 0.8$ \\
Nickel (Ni) & $34.05 \pm 2.4$ \\
Copper (Cu) & $8.84 \pm 0.4$ \\
Mercury (Hg) & $<0.003$ \\
Zinc (Zn) & $122.2 \pm 0.1$ \\
Arsenic (As) & $1.12 \pm 0.08$ \\
Potassium (K) & $45 \pm 0.1$ \\
Iron (Fe) & $80 \pm 1.4$ \\
Manganese (Mn) & $124 \pm 1.6$ \\
Magnesium (Mg) & $139 \pm 2.42$ \\
Sodium (Na) & $223 \pm 2.8$ \\
\hline
\end{tabular}

properties were improved after irradiation and optimum result was found at (10-15) kGy gamma-radiation doses. Total nitrogen and ammonium content in the textile effluent has been increased after irradiation, which indicated the possibility of the textile effluent to be used as fertilizercontaining irrigation water. And it is also proved by the enhanced growth rate of spleen amaranth irrigated by gamma ray-irradiated textile effluent compared to that of the plant nourished with the raw textile effluent and only water. The elemental analysis revealed that the plants uptake trace amount of heavy metal and moreover contain satisfactory amount of mineral nutrients. At the dose rate of $(10-15) \mathrm{kGy}$ the psychochemical parameter as well as the plant production is satisfactory. All the results indentified that the treatment of textile effluents by gamma irradiation $(10-15 \mathrm{kGy})$ is a promising tool as it produces zero waste and has the possibility of alternative use for irrigation water with fertilizing properties.

Open Access This article is distributed under the terms of the Creative Commons Attribution License which permits any use, distribution, and reproduction in any medium, provided the original author(s) and the source are credited.

\section{References}

Anbar M, Neta P (1967) Radiation chemical destruction of phenol in oxygenated aqueous solutions. Int J Appl Radiat Isot 18:493

Bagyo ANM, Arai H, Miyata T (1997) Radiation-induced decoloration and sedimentation of colloidal disperse dyes in water. App Radiat Isot 48:175-181

Buxton GV, Greenstock CL, Helman WP, Ross AB (1988) Critical review of rate constants for reactions of hydrated electrons, hydrogen atoms and hydroxyl radicals in aqueous solution. J Phys Chem Ref Data 17(2):513-886

Compton DMJ (1971) Destruction of organic substances in waste water by ionizing radiation. Isot Radiat Technol 18:453
Dahlan KZM (2001) Radiation sciences. Advances in tissue banking, vol 5. World Scientific Publishing Co. Pte. Ltd

GoB (Government of Bangladesh) (1997) Environment conservation rules, ECR-Schedule 3, Standards for water

Grubben GJH, Denton OA (2004) Plant resources of tropical Africa 2. Vegetables. PROTA Foundation, Wageningen; Backhuys, Leiden; CTA, Wageningen

Islam JMM, Habib SMA, Parvin F, Rahman MF, Saadat AHM, Khan MA (2013) Removal of industrial dye effluent (drimarene yellow) by renewable natural resources. Am Acad Scholar Res J 5:144-150

Itanna F (2002) Metals in leafy vegetables grown in Addis Ababa and toxicological implications. Ethiop J Health Dev 16(3):295-302

Kim TH, Park C, Lee J, Shin EB, Kim S (2002) Comparison of disperse and reactive dye removals by chemical coagulation and Fenton oxidation. J Hazard Matter 112:95-103. doi:10.1016/j. jhazmat.2004.04.008

Miyata T (1993) Liquid wastes chemistry, UNDP/IAEA/RCA regional training course on radiation technology for environmental conservation, JAERI

Mollah MZI, Khan MA, Khan RA (2009) Effect of gamma irradiated sodium alginate on red amaranth (Amaranthus cruentus L.) as growth promoter. J Radiat Phys Chem 78:61-64. doi:10.1016/j. radphyschem.2008.08.002

Mulvaney RL (1996) Nitrogen-inorganic forms. Methods of soil analysis, part 3-chemical methods. Soil Science Society of America, Madison, pp 1129-1139

Naser HM, Sultana S, Mahmud NU, Gomes R, Noor S (2011) Heavy metal levels in vegetables with growth stage and plant species variations. Bangladesh J Agric Res 36(4):563-574. doi:10.3329/bjar.v36i4. 11743

Nickelsen MG, Cooper WJ, Waite TD, Kurucz CN (1992) Removal of benzene and selected alkyl substituted benzenes from aqueous solution utilizing continuous high-energy electron irradiation. Environ Sci Technol 26:144-152

Panda GC, Das SK, Guha AK (2009) Jute stick powder as a potential biomass for the removal of congo red and rhodamine B from their aqueous solution. J Hazard Mater 164:374-379. doi:10. 1016/j.jhazmat.2008.08.015

Parvin F, Yeasmin F, Islam JMM, Molla E, Khan MA (2013) Effect of gamma irradiated sodium alginate on Malabar spinach (Basella alba) and spinach (Spinacia oleracea) as plant growth promoter. Am Acad Sch Res J 5(5):63-71

Rabby F (2011) Radiation induced waste water treatment in textile industry. Bangladesh Textile Today, Dhaka

Rouse RD (1979) Water quality management in pond fish culture. In: Research and development series no. 22, Project: AID/DSAN-G 0039, Auburn University, Alabama

Selambakkannu S, Bakar KA, Ming TT, Sharif J (2011) Effect of gamma and electron beam irradiation on textile waste water. J Sains Nukl Malays 23(2):67-73

Somasiri W, Ruan W, Xiufen L, Jian C (2006) Decolorization of textile wastewater containing acid dyes in UASB reactor system under mixed anaerobic granular sludge. Electron J Environ Agric Food Chem 5(1):1224-1234

Soutsus K, Karyannis V, Poulios I, Riga A (2010) Decoloration and degradation of reactive Azo dyes via heterogeneous photo catalytic processes. Desalination 250:345-350. doi:10.1016/j. desal.2009.09.054

Spinks JWT, Woods RJ (1964) An introduction to radiation chemistry, vol 8. Wiley, New York

Sumartono A (2006) Degradation of standard dyes and textile wastewater as a pollutant model using gamma radiation. Indones J Chem 6(3):225-230

Suzuki N, Nagai T, Hotta H, Washino M (1975) The radiation-induced degradation of azo dyes in aqueous solutions. Int J Appl Radiat Isot 26(12):726-730. doi:10.1016/0020-708X(75)90129-5 
Takács E, Wojnárovits L, Pálfi T (2007) Azo dye degradation by high-energy irradiation: kinetics and mechanism of destruction. Nukleonika 52(2):69-75

Tchobanoglous G, Schroeder ED (1985) Water quality: characteristics, modeling and modification. Addison-Wesley Publishing Company, Canada

United States Environmental Protection Agency (1995) Water quality standards revision of metals criteria. Federal Regist 60:22229-22237
Wang M, Yang R, Wang W, Shen Z, Bian S, Zhu Z (2006) Radiationinduced decomposition and decoloration of reactive dyes in the presence of $\mathrm{H}_{2} \mathrm{O}_{2}$. Radiat Phys Chem 75(2):286-291. doi:10. 1016/j.radphyschem.2005.08.012

WHO (World Health Organization) (2000) WHO water quality guidelines, 2nd edn. World Health Organization, Europe Regional Office, Copenhagen 